\title{
PENGARUH PROFITABILITAS TERHADAP RETURN SAHAM DENGAN NILAI PERUSAHAAN SEBAGAI VARIABEL MEDIASI PADA INDEKS SAHAM SYARIAH INDONESIA SEKTOR INDUSTRI BARANG KONSUMSI PERIODE 2013-2017
}

\author{
Destiana Kumala1 ${ }^{1}$ ), Iyan Nurhasni Ahya ${ }^{2}$ ) \\ 1)AMIK LAKSI 31, Jakarta ${ }^{2}$ ) Universitas Negeri Jakarta \\ Email1destiana.kumala86@gmail.com \\ Email2ianoahya@gmail.com
}

\begin{abstract}
Abstrak
Penelitian ini bertujuan untuk menguji pengaruh profitabilitas terhadap return saham dengan nilai perusahaan sebagai variabel mediasi. Populasi dalam penelitian ini adalah perusahaan manufaktur sektor industri barang konsumsi yang terdaftar dalam Indonesian Sharia Shock Index (ISSI), variabel independen dalam penelitian ini adalah profitabilitas $(\mathrm{X})$, diproksikan dengan return on equity, variabel dependen saham. kembali (Y). Yang diukur dengan perhitungan rumus return saham dan variabel mediasi yaitu nilai perusahaan $(Z)$ diproksikan dengan price to book value (PBV). Metode penelitian ini menggunakan metode penelitian kuantitatif dengan menggunakan data sekunder. Sampel diambil berdasarkan kriteria yang telah ditentukan. Dari metode pengambilan sampel yang diterapkan, diperoleh 13 perusahaan manufaktur sektor industri barang konsumsi yang terdaftar di Indeks Saham Syariah Indonesia (ISSI) 2013 - 2017 dengan analisis data menggunakan program SPSS 22. Hasil penelitian menunjukkan bahwa profitabilitas berpengaruh terhadap nilai perusahaan, profitabilitas tidak berpengaruh terhadap return saham, nilai perusahaan berpengaruh terhadap return saham, profitabilitas berpengaruh terhadap return saham yang dimediasi oleh nilai perusahaan.
\end{abstract}

Kata kunci: profitabilitas, return saham, nilai perusahaan

\section{EFFECT OF PROFITABILITY ON SHARE RETURN WITH COMPANY VALUE AS A MEDIATION VARIABLES IN INDONESIA SHARES INDEX IN THE CONSUMPTION GOODS INDUSTRY SECTOR 2013-2017}

\begin{abstract}
This study aims to examine the effect of profitability on stock returns with firm value as the mediating variable. The population in this study are manufacturing companies in the consumer goods industry sector which are listed on the Indonesian Sharia Shock. Index (ISSI), the independent variable in this study is profitabilty (X), proxied by using return on equity, the dependent variable stock returns (Y). As measured by the calculation of the stock return formula and the mediating variable, namely the firm value $(Z)$ is proxied by the price to book value (PBV). This research method uses quantitative research methods using secondary data. Samples were taken based on predetermined criteria. From the sampling method applied, it was obtained 13 manufacturing companies in the consumer goods industry sector that were listed on the Indonesia Sharia Stock Index (ISSI) 2013 - 2017 with data analysis using the SPSS 22 program. The results showed that profitability had an effect on firm value, profitability had no effect on stock return, firm value had an effect on stock returns, profitability had an effect on stock returns mediated by firm value. keywords : profitability,stock return, firm value
\end{abstract}




\section{PENDAHULUAN}

Bagi para investor, return merupakan salah satu parameter untuk menilai seberapa besar keuntungan suatu saham. Investor yang akan berinvestasi di pasar modal terlebih dahulu melihat saham perusahaan mana yang paling menguntungkan, dengan menilai kinerja perusahaan yang bersangkutan. Perusahaan yang memiliki kinerja cukup baik akan lebih diminati oleh para investor, karena kinerja perusahaan mempengaruhi harga saham di pasar. Investor akan membeli saham sesuai kinerja perusahaan saat ini dan prospeknya di masa yang akan datang. ${ }^{1}$

Salah satu cara untuk menganalisis kinerja keuangan adalah menggunakan rasio keuangan. Pengukuran kinerja keuangan meliputi hasil perhitungan rasio-rasio keuangan yang berbasis pada laporan keuangan perusahaan yang dipublikasikan dan telah diaudit oleh akuntan publik. Rasio keuangan dikelompokan menjadi beberapa kelompok antara lain, rasio profitabilitas.

Rasio profitabilitas digunakan untuk mengukur efektifitas manajemen berdasarkan hasil pengembalian dari penjualan investasi serta kemampuan perusahaan menghasilkan laba (profit) yang akan menjadi dasar pembagian dividen perusahaan. Dalam penelitian ini rasio profitabilitas diukur menggunakan Return on Equity (ROE). ROE digunakan untuk mengukur kinerja manajemen perusahaan dalam mengelola modal yang tersedia untuk menghasilkan laba setelah pajak ${ }^{2}$. Kenaikan rasio ini berarti terjadi kenaikan laba bersih dari perusahaan yang bersangkutan, sehingga para investor akan tertarik untuk menanamkan modalnya pada perusahaan. Ketika permintaan saham meningkat, maka harga saham akan naik. Kenaikan harga saham akan mengakibatkan return saham perusahaan akan naik pula, demikian sebaliknya. ${ }^{3}$

Selain mengestimasi nilai-nilai faktor fundamental melalui rasio keuangan, investor pada umumnya juga memperhatikan nilai perusahaanya. Nilai perusahaan merupakan persepsi investor terhadap tingkat keberhasilan perusahaan dan sering dikaitkan dengan harga saham. ${ }^{4}$ Nilai perusahaan lazim di ukur dengan Price to Book V alue (PBV) yang merupakan suatu nilai yang dapat digunakan untuk membandingkan apakah sebuah saham lebih mahal atau lebih murah dibandingkan dengan saham lainya. Nilai PBV semakin besar menunjukan harga pasar semakin tinggi pula. Jika harga pasar meningkat maka capital gain (actual return) dari saham tersebut juga akan meningkat. ${ }^{5}$

Seorang muslim tentunya menginginkan investasi yang sesuai dengan aturan agama Islam. Salah satunya dengan berinvestasi pada efek syariah yang terdaftar di Indeks Saham Syariah Indonesia (ISSI). Sejak November 2007, Bapepam LK (sekarang menjadi OJK)

\footnotetext{
${ }^{1}$ Rika Verawati. 2013. Faktor-Faktor Penentu Yang Mempengaruhi Return Saham Perusahaan Manufaktur Yang Terdaftar Di Bursa Efek Indonesia (BEI) Periode 2008-2013, Skripsi, Fakultas Ekonomi Universitas Negeri Yogyakarta, hal 18.

${ }^{2}$ Lany Astiyani. 2017. Pengaruh Profitabilitas Dan Leverage Terhadap Return Saham (Studi Kasus pada Bursa Efek Indonesia Tahun 2012-2016). Skripsi, Program Studi Akuntansi Fakultas Ekonomi dan Bisnis Universitas Pasundan Bandung, hal 6.

${ }^{3}$ I Gusti Ayu Ika Yuni Nandani dan Luh Komang Sudjarni. 2017. Pengaruh Likuiditas, Profitabilitas Dan Nilai Pasar Terhadap Return Saham Perusahaan F \& B Di BEI, E-Jurnal Manajemen Universitas Udayana, Vol. 6 No. 8, hal 4481-4509.

${ }^{4}$ Dewi Kusuma Wardani dan Sri Hemuningsih. 2016. Pengaruh Struktur Kepemilikan Terhadap Nilai Perusahaan Dengan Kinerja Keuangan dan Kebijakan Hutang Sebagai Variabel Intervening, Universitas Sarjanawiyata Tamansiswa:Jurnal Siasat Bisnis Vol 15 No 1, hal 27-36.

${ }^{5}$ Lidia Desiana, Op. Cit., hal 225.
} 
telah mengeluarkan Daftar Efek Syariah (DES) yang berisi daftar saham syariah yang ada di Indonesia. Keberadaan DES tersebut kemudian ditindak lanjuti oleh BEI dengan meluncurkan Indeks Saham Syariah Indonesia (ISSI) pada tanggal 12 Mei 2011. Konstituen ISSI terdiri dari seluruh saham syariah yang tercatat di BEI. ${ }^{6}$

Salah satu sektor yang terdapat di ISSI adalah sektor industri barang konsumsi. Peluang bagi investor dalam menanamkan investasi pada sektor industri barang konsumsi, karena masyarakat Indonesia cendrung bersifat konsumtif dalam pemenuhan kebutuhan pokok dalam hal sandang, pangan, dan papan. Seiring tingkat pertumbuhan penduduk Indonesia yang terus meningkat, maka pemakaian akan produk sektor industri ini juga akan meningkat. ${ }^{7}$ Sehingga investasi di perusahaan sektor industri barang konsumsi menjadi alternatif yang dapat dipertimbangkan. Berikut data rata-rata return saham pada perusahaan manufaktur sektor industri barang konsumsi yang terdaftar di Indeks Saham Syariah Indonesia (ISSI) 2013- 2017 yang ditunjukan oleh tabel 1:

Tabel 1: Rata-rata Return Saham Perusahaan Manufaktur Sektor Industri Barang Konsumsi yang terdaftar di ISSI Tahun 2013- 2017

\begin{tabular}{cccccc}
\hline Tahun & $\mathbf{2 0 1 3}$ & $\mathbf{2 0 1 4}$ & $\mathbf{2 0 1 5}$ & $\mathbf{2 0 1 6}$ & $\mathbf{2 0 1 7}$ \\
\hline Return Saham & $1,79 \%$ & $1,94 \%$ & $1,28 \%$ & $1,55 \%$ & $2,32 \%$ \\
\hline
\end{tabular}

Sumber : www.idx.co.id diakses 1 Mei 2019 (diolah)

Berdasarkan tabel 1 dapat dilihat bahwa return saham sektor industri barang konsumsi pada tahun 2017 menjadi yang tertinggi selama kurun waktu 2013-2017 dengan rata-rata return sebesar 2,32\%, berbeda dengan tahun 2015 yang menjadi terendah dengan return sebesar 1,28\%. Selain data rata-rata return saham, berikut juga data rata-rata rasio profitabilitas yang diproksikan dengan ROE perusahaan manufaktur sektor industri barang konsumsi yang terdaftar di Indeks Saham Syariah Indonesia (ISSI) 2013- 2017 yang ditunjukan oleh tabel 2:

Tabel 2: Rata-rata Profitabilitas Perusahaan Manufaktur Sektor Industri Barang Konsumsi yang terdaftar di ISSI Tahun 2013- 2017

\begin{tabular}{cccccc}
\hline Tahun & $\mathbf{2 0 1 3}$ & $\mathbf{2 0 1 4}$ & $\mathbf{2 0 1 5}$ & $\mathbf{2 0 1 6}$ & $\mathbf{2 0 1 7}$ \\
\hline Profitabilitas (ROE) & $12,34 \%$ & $9,97 \%$ & $7,97 \%$ & $8,94 \%$ & $6,47 \%$ \\
\hline
\end{tabular}

Sumber : www.idx.co.id diakses pada 1 Juli 2019 (diolah)

Rata-rata profitabilitas pada tabel diatas menunjukan angka tertinggi pada tahun 2013 yaitu sebesar 12,34\% dan terendah pada tahun 2017 sebesar 6,46\%. Secara keseluruhan rata-rata return saham dan profitabilitas pada kedua tabel diatas mengalami fluktuatif, sehingga dapat disimpulkan bahwa tingkat return saham perusahaan manufaktur sektor industri barang konsumsi yang terdaftar di ISSI tahun 2013-2017 dipengaruhi oleh pergerakan profitabilitas.

Menurut Eugenen, F.Brigham dan Joel,F. Houstom ${ }^{8}$ menyatakan bahwa investor menganggap perubahan dividen sebagai sinyal dari perkiraan pendapat manajemen

${ }^{6}$ www.idx.co.id (diakses pada 7 Mei 2019).

${ }^{7}$ Titin Hartini. 2017. Pengujian Koalisi Debt To Equity Ratio (DER) dan Earning Per Share (EPS) Terhadap Harga Saham (Studi Kasus Empiris Pada Perusahaan Sektor Makanan Dan Minuman Yang Terdaftar Di Indeks Saham Syariah Indonesia). Jurnal I-Finance Vol.1 No.1, Fakultas Ekonomi dan Bisnis Islam UIN Raden Fatah Palembang, hal 22.

${ }^{8}$ Eugenen, F. Brigham dan Joel, F. Houstom. 2011. Manajemen Keuangan. Manajemen Keuangan. Jakarta :Repository.stainkudus.ac.id/4545/5/5/Erlangga. Hlm 36 
perusahaan sehingga informasi menyatakan suatu hal yang penting bagi investor karena pada umumnya menyajikan catatan atau keterangan perusahaan baik masa lalu maupun saat ini bagi kelangsungan perusahaan dan efeknya bagi pengembangan perusahaan.

Suatu informasi yang akurat, tepat, lengkap dan relevan sangat diperlukan oleh investor di pasar modal dan dijadikan sebagai alat ukur untuk menganalisis dalam mengambil keputusan investasi. Informasi yang disebar luaskan dapat memberikan sinyal kepada investor dan masyarakat luas dalam mengambil keputusan investasi. Informasi tersebut berperan penting, karena memberikan pengaruh pada keputusan yang akan diambil oleh pihak luar dan jika pihak luar tidak memiliki informasi yang cukup dalam menilai suatu perusahaan,maka cenderung melindungi diri dan mencari titik aman dengan memberikan harga rendah untuk perusahaan?

Menurut Jogiyanto $^{10}$, Return merupakan hasil yang diperoleh dari investasi. Dalam berinvestasi seorang investor pasti mengharapkan keuntungan (return) dan tidak mungkin mau untuk melakukan investasi yang tidak menghasilkan keuntungan. Return saham (capital gain atau capital loss) adalah selisih dari harga harga investasi sekarang relatif dengan harga periode tertentu. Return ini sangat penting karena dapat digunakan sebagai salah satu penguku kinerja perusahaan dan dapat digunakan sebagai dasar penentu return ekspektasian. Return ekspektasian (return yang diharapkan) adalah return yang diharapkan akan diperoleh oleh investor di masa mendatang. Return realisasian ini dapat digunakan sebagai pertimbangan dalam pengambilan keputusan investasi. ${ }^{11}$

Profitabilitas merupakan kemampuan suatu perusahaan untuk mendapatkan laba (keuntungan) dalam suatu proses melalui semua kemampuan dan sumber daya yang ada seperti kegiataan penjualan, kas, modal jumlah karyawan dan sebagainya sejauh mana perusahaan menghasilkan laba dari penjualan dan investasi perusahaan ${ }^{12}$. Rasio yang digunakan adalah return on aset (ROA) untuk mengukur keuntungan bersih yang diperoleh dari penggunaan aktiva.

Peningkatan daya tarik perusahaan menjadikan perusahaan tersebut semakin diminati investor, karena tingkat pengembalian akan semakin besar. Hal ini juga berdampak bahwa harga saham dari perusahaan tersebut di pasar modal juga akan semakin meningkat sehingga ROA akan berpengaruh terhadap harga saham perusahaan. return on aset mencerminkan seberapa besar return yang dihasilkan atas setiap rupiah uang yang ditanam dalam bentuk aset ${ }^{13}$

Nilai perusahaan merupakan persepsi investor terhadap tingkat keberhasilan perusahaan yang terkait erat dengan harga saham ${ }^{14}$. Nilai perusahaan yang dibentuk melalui indikator pasar saham, sangat dipengaruhi oleh peluang-peluang investasi. Pengeluaran investasi memberikan sinyal dari investasi kepada manajer tentang pertumbuhan

${ }^{9}$ Zainal Arifin.,2005. Teori Keuangan dan Pasar Modal Ekonosia. Yogjakarta. HIm 11

${ }^{10}$ Jogiyanto Hartono. 2014. Teori Portofolio dan Analisis Investasi. Yogyakarta:BPFEYogyakarta, hal 263.

${ }^{11}$ Ibid, hal 264.

${ }^{12}$ Sofyan Syafri Harapah, 2006. Analisis Kritis atas Laporan Kenangan. Jakarta: PT Raja Grafindo Persada. Hlm 304

${ }^{13}$ Wenner R. Murhadi, 2013. Analisis Laporan Keuangan Proyeksi dan Valuasi Saham. Jakarta : Salemba Empat. Hlm 64

${ }^{14}$ Muhammadinah, 2016. Pengaruh Profitabilitas, Resiko Keuangan, Ukuran Perusahaan, Growth, Struktur Kepemilikan Manajerial dan Dividend Payout Ratio terhadap Manajemen Laba pada Perusahaan Sektor Perbankan yang Terdaftar di Bursa Efek Indonesia. Halaman 40 
perusahaan dimasa yang akan datang, sehingga meningkatkan harga saham sebagai indikator nilai perusahaan.

Pada penelitian ini alat ukur yang digunakan untuk menghitung nilai perusahaan ialah price book value (PBV) yang merupakan salah satu rasio nilai perusahaan dalam pengambilan keputusan investasi, nilai buku merupakan ukuran stabil dan sederhana yang dapat dibandingkan dengan harga saham dan dapat dibandingkan antara perusahaan sejenis yang menunjukan tanda mahal atau murahnya suatu saham.

Berdasarkan pemaparan latar belakang dan tinjauan pustaka di atas, maka perumusan hipotesis dapat di tunjukan dalam kerangka pemikiran sebagai berikut:

\section{Gambar 1: Kerangka Pemikiran Penelitian}

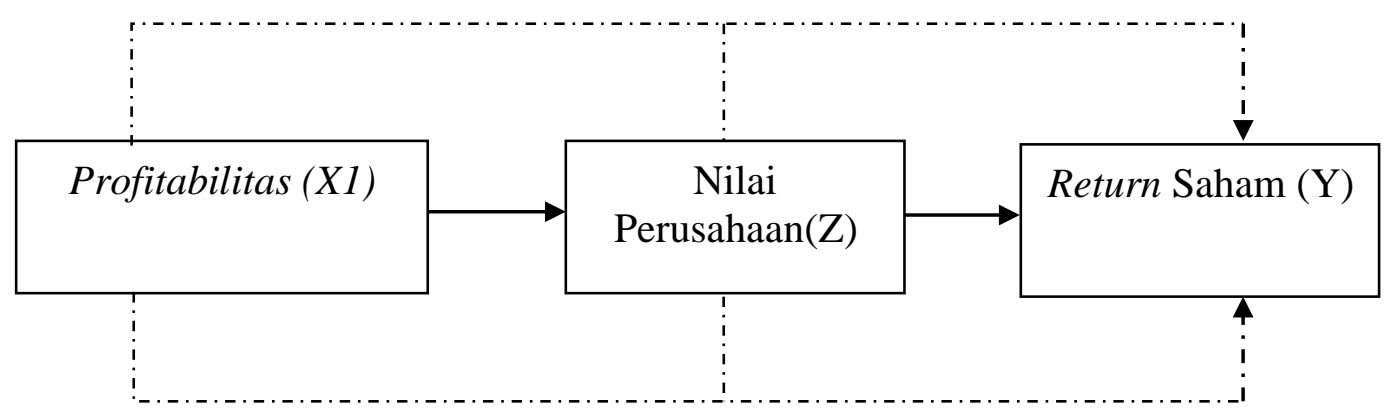

\section{Pengaruh Profitabilitas terhadap Nilai Perusahaan}

Penelitian sebelumnya yang dilakukan Loh Wenny Setiawati dan Melliana Lim ${ }^{15}$ menyatakan profitabilitas berpengaruh positif dan signifikan terhadap nilai perusahaan dengan perolehan nilai signifikannya sebesar $0,000<$ standar 0,05 , nilai $\mathrm{T}$ hitung sebesar 13,774 > nilai T tabel 1,96958. Peningkatan margin laba akan meningkatkan kemmapuan perusahaan dalam menghasilkan dana internal. Dengan demikian investor akan tertarik untuk berinvestasi dan harga saham pun meningkat, hal tersebut akan meningkatkan nilai perusahaan pula.

\section{H1 : Profitabilitas berpengaruh terhadap nilai perusahaan}

\section{Pengaruh Profitabilitas terhadap Return Saham}

Penelitian I Gusti Ayu Ika Yuni Nandani dan Luh Komang Sudjarni ${ }^{16}$ tentang pengaruh profitabilitas terhadap return saham dengan perolehan nilai signifikannya sebesar $0,001<$ standar alpha 0,05 , nilai $\mathrm{T}$ hitung sebesar 3,550 > nilai $\mathrm{T}$ tabel serta hasil uji determinasi sebesar 0, 388 atau sebesar 38,8\% menunjukan bahwa profitabilitas memiliki pengaruh positif terhadap return saham. Nilai ROE yang tinggi dapat diartikan bahwa perusahaan mampu menaikan laba bersih dengan modal sendiri yang dimiliki oleh

${ }^{15}$ Loh Wenny Setiawati dan Melliana Lim. 2017. “Analisis Pengaruh Profitabilitas, Ukuran Perusahaan, Leverage, Dan Pengungkapan Sosial Terhadap Nilai Perusahaan Pada Perusahaan Manufaktur Yang Terdaftar Di Bursa Efek Indonesia Periode 2011-2015". Jurnal Akuntansi FE UNIKA Atma Jaya, Vol 12. No.1. hal 29-57.

${ }^{16}$ I Gusti Ayu Ika Yuni Nandani. Luh Komang Sudjarni. 2017. "Pengaruh Likuiditas, Profitabilitas Dan Nilai Pasar Terhadap Return Saham Perusahaan F \& B Di BEI", E-Journal Manajemen Unud. Vol. 6, No. 8. hal 4481-4509. 
perusahaan. Hal tersebut akan menarik minat investor untuk menanamkan modalnya, sehingga akan menaikan harga saham begitupun dengan return.

\section{H2 : Profitabilitas berpengaruh terhadap Return Saham}

\section{Pengaruh Nilai Perusahaan terhadap Return Saham}

Septy Kurnia Fidhayatin dan Nurul Hasanah Uswati Dewi ${ }^{17}$ melakukan penelitian hasil nilai perusahaan berpengaruh positif terhadap return saham dengan nilai signifikansinya sebesar $0,000<$ standar alpha 0,05, serta hasil uji determinasi sebesar 0,166 atau sebesar $16,6 \%$. Semakin tinggi nilai perusahaan maka akan semakin tinggi tingkat kepercayaan pasar terhadap prospek perusahaan. Hal tersebut akan menjadi daya tarik investor untuk membeli saham sehingga permintaan akan saham naik kemudian mendorong harga saham meningkat.

\section{H3 : Nilai perusahaan berpengaruh terhadap return saham}

\section{Pengaruh Nilai Perusahaan Sebagai Intervening Antara Profitabilitas Terhadap Return Saham}

Penelitian Sekar Aditya Dwikirana dan prastiono tentang pengaruh profitabilitas terhadap return saham dengan nilai perusahaan sebagai varabel mediasi, berdasarkan pengujian sobel test nilai t hitung $=6,0165$ lebih besar dari t tabel dengan tingkat signifikansi 0,05 yaitu 1,96 menunjukan bahwa nilai perusahaan memediasi hubungan antara Profitabilitas terhadap return saham. Berdasarkan hasil penelitian yang telah dilakukan, maka hipotesis dalam penelitian ini adalah:

H4 : Profitabilitas berpengaruh positif terhadap return saham melalui nilai perusahaan.

\section{METODE PENELITIAN}

\section{Desain Penelitian}

Jenis penelitian yang digunakan dalam penelitian ini adalah penelitian kuantitatif dengan mengunakan data sekunder. Teknik pengambilan sampel mengunakian purposive sampling dan berdasarkan kriteria yang telah ditentukan sebelumnya. Dari metode sampling yang diterapkan diperoleh 13 perusahaan manufaktur sektor industri barang konsumsi yang terdaftar di Indeks Saham Syariah Indonesia (ISSI) periode 2013 -2017. Teknik analisis data mengunakan analisis regresi dan analisis jalur dengan menggunakan SPSS 22.

\section{Variabel Penelitian dan Definisi Operasional Perusahaan}

Penelitian ini menggunakan berbagai variabel untuk melakukan analisis data. Variabel tersebut terdiri dari variabel dependen, variabel independen dan variabel mediasi. Variabel dependen dalam penelitian ini ialah return saham, untuk variabel independen adalah profitabilitas dan untuk variabel mediasi ialah nilai perusahaan.

\footnotetext{
${ }^{17}$ Septy Kurnia Fidhayatin dan Nurul Hasanah Uswati Dewi. 2014. “Analisa Nilai Perusahaan, Kinerja Perusahaan Dan Kesempatan Bertumbuh Perusahaan Terhadap Return Saham Pada Perusahaan Manufaktur Yang Listing Di BEI', The Indonesian Accounting Review. Vol. 2, No. 2. Hal 204-214.
} 


\section{Return Saham}

Pada penelitian ini variabel dependen atau terikat yang digunakan adalah return saham. Return saham (capital gain atau capital loss) merupakan selisih dari harga investasi sekarang relatif dengan harga periode tertentu.dirumuskan sebagai berikut :

Return $=\frac{P t-\left(P t_{-1}\right)}{P t_{-1}}$

\section{Profitabilitas}

Rasio yang digunakan untuk mengukur kemapuan perusahaan dalam menghasilkan laba dari aktivitas normal bisnisnya, profitabilitas dituntut untuk meningkatkan kinerja perusahaan. banyak jenis-jenis profitabilitas namun yang dipakai pada penelitian adalah rasio return on asset (ROA). dirumuskan sebagai berikut :

$$
R O A=\frac{\text { Laba Setelah Pajak }}{\text { Total Asset }}
$$

\section{Nilai Perusahaan}

Nilai perusahaan yang merupakan keadaan yang mengambarkan suatu perusahaan, nilai perusahaan dapat diukur mengunakan rasio price book value (PBV) yang merupakan rasio pasar untuk mengukur kinerja harga pasar saham terhadap nilai bukunya. Semakin tinggi rasio tersebut maka semakin berhasil perusahaan menciptakan nilai bagi pemegang saham. Dengan rumus sebagai berikut :

$P B V=\frac{\text { Harga Pasar }}{\text { Book Value }}$

\section{Populasi dan Sampel Penelitian}

Populasi pada penelitian ini adalah perusahaan-perusahaan manufaktur sektor industri barang konsumsi yang terdaftar di Indeks Saham Syariah Indonesia (ISSI) periode 2013 - 2017 sebanyak 37 perusahaan. metode penelitian sampel yang digunakan dalam penelitian adalah purposive sampling yaitu pemilihan yang sampel dipilih dengan menggunakan kriteria tertentu. Tujuan dari penggunaan kriteria pemilihan sampel ini adalah untuk mempersempit area penelitian yang digunakan dalam sampel penelitian adalah sebagai berikut:

1. Jumlah perusahaan manufaktur sektor industri barang konsumsi yang terdaftar di ISSI periode 2013-2017

2. Jumlah perusahaan manufaktur sektor industri barang konsumsi yang terdaftar di ISSI periode 2013-2017 (yang konsisten/tetap)

3. Mencantumkan variabel-variabel penelitian yang dibutuhkan pada laporan keuangan selama periode 2013-2017

4. Jumlah data sampel dari 13 perusahaan selama periode 5 tahun

\section{Jenis dan Sumber Data}

Jenis penelitian yang digunakan dalam penelitian ini adalah penelitian asosiatif kausal dengan pendekatan kuantitatif dan menggunakan data sekunder, yaitu sumber data yang diperoleh secara tidak langsung dan menggunakan media perantara yaitu annual repost 
perusahaan yang didalamnya terdapat laporan keuangan pada perusahaan yang terdaftar di Indeks Saham Syariah Indonesia (ISSI) periode 2013 -2017. Melalui situs www.ojk.go.id dan www.idx.co.id

\section{Metode Analisis}

Metode analisis data yang digunakan dalam penelitian ini adalah dengan menggunakan metode kuantitatif. Pendekatan kuantitatif menurut Cooper dan Schindler riset kuantitatif melakukan pengukuran yang lebih akurat terhadap suatu objek, proses dari penelitian ini menggunakan metode kuantitatif yang memuat pengujian dan melakukan verifikasi terhadap kebenaran teori tersebut ${ }^{18}$.

\section{HASIL PENELITIAN}

Pengujian Hipotesis

Uji Multikolinieritas

Berikut tabel hasil uji multikolinearitas :

\section{Tabel 3: Uji Multikolinieritas}

\begin{tabular}{ccc}
\hline \multirow{2}{*}{ Model } & \multicolumn{2}{c}{$\begin{array}{c}\text { Collinearity } \\
\text { Statistics }\end{array}$} \\
\cline { 2 - 3 } & \multicolumn{2}{c}{ Persamaan 3 } \\
\cline { 2 - 3 } & Tolerance & VIF \\
\hline Profitabilitas & 0,502 & 1,991 \\
\hline Leverage & 0,981 & 1,020 \\
\hline Nilai Perusahaan & 0,502 & 1,993 \\
\hline
\end{tabular}

Sumber : Data diolah, 2019

Berdasarkan tabel 3 dapat dilihat bahwa nilai Tolerance pada persamaan semua variabel independen menunjukkan hasil $<0,1$ begitupula dengan nilai Variance Inflation Factor (VIF) dari semua variabel independen menunjukkan hasil $<10$ sehingga bisa disimpulkan bahwa tidak terjadi multikolinearitas.

\section{Analisis Substruktural I}

$\mathrm{Z}(\mathrm{PBV})=\beta \mathrm{ROE}+\mathrm{e} 1$ (Persamaan struktural I).

Berikut gambar dari persamaan struktural I:

\section{Gambar 2: Persamaan Struktur I}

\section{Profitabilitas $(X) \longrightarrow$ Nilai Perusahaan $(Z)$}

4:

Pengujian hipotesis dari persamaan struktural II akan dijelaskan oleh beberapa tabel

18 Muhajirin dan Maya Panorama. 2017. Pendekatan Praktis Metode Penilaian Kualitatif dan Kuantitatif. Idea Press: Yogyakarta,. hlm 50 
Tabel 4: Pengaruh Profitabilitas terhadap Nilai Perusahaan

\begin{tabular}{lllrl}
\hline Model & \multicolumn{1}{c}{$\begin{array}{c}\text { Standardized } \\
\text { Coefficients } \\
\text { Beta }\end{array}$} & T & Sig. \\
\hline (Constant) & & & $-3,657$ & 0,001 \\
\cline { 2 - 6 } & Profitabilitas & 0,700 & 7,772 & 0,000 \\
\hline
\end{tabular}

Sumber : Data diolah, 2019

Jika t-hitung $>$ t-tabel atau $(-)$ t-hitung $<(-)$ t-tabel, maka $\mathrm{H}_{\mathrm{o}}$ ditolak dan $\mathrm{H}_{\mathrm{a}}$ diterima dan sebaliknya jika t-hitung $<$ t-tabel atau $(-)$ t-hitung $>(-)$ t-tabel, maka $\mathrm{H}_{\mathrm{o}}$ diterima dan $\mathrm{H}_{\mathrm{a}}$ ditolak. Besarnya angka t-tabel dengan taraf signifikansi 0,05 dan derajat kebebasan $(\mathrm{dk})=(\mathrm{n}-2)=(65-2)=63$. Dari ketentuan tersebut diperoleh angka t-tabel sebesar 1,66940. Berdasarkan hasil perhitungan, diperoleh angka t-hitung sebesar 7,772 > ttabel sebesar 1,669, sehingga $\mathrm{H}_{\circ}$ ditolak dan $\mathrm{H}_{\mathrm{a}}$ diterima. Artinya ada pengaruh profitabilitas terhadap nilai perusahaan. Besarnya pengaruh positif profitabilitas terhadap nilai perusahaan adalah 0,700 atau sebesar $70 \%$ dan signifikan karena nilai signifikansinya sebesar $0,000<\alpha 0,05$. Untuk melihat seberapa besar pengaruh variabel yang diteliti terhadap variabel nilai perusahaan dapat dilihat berdasarkan tabel 5:

Tabel 5: Model Summary

\begin{tabular}{cc}
\hline Model & R Square \\
\hline $\mathbf{1}$ & 0,490 \\
\hline
\end{tabular}

Sumber : Data diolah, 2019

Berdasarkan Tabel 5 diperoleh nilai $\mathrm{R}$ Square sebesar 0,490. Angka tersebut mempunyai arti bahwa pengaruh profitabilitas terhadap nilai perusahaan adalah 49\%. Artinya, sebesar 49\% variabel nilai perusahaan bisa dijelaskan oleh variabel independen dalam penelitian, yaitu variabel profitabilitas sedangkan sisanya $51 \%$ dijelaskan oleh variabel lain yang tidak diteliti dalam penelitian ini.

\section{Analisis Substruktural II}

$\mathrm{Y}($ Return Saham $)=\beta \mathrm{ROE}+\beta \mathrm{PBV}+\mathrm{e} 1$.

Berikut gambar dari persamaan struktural II:

\section{Gambar 3: Persamaan Struktural II}

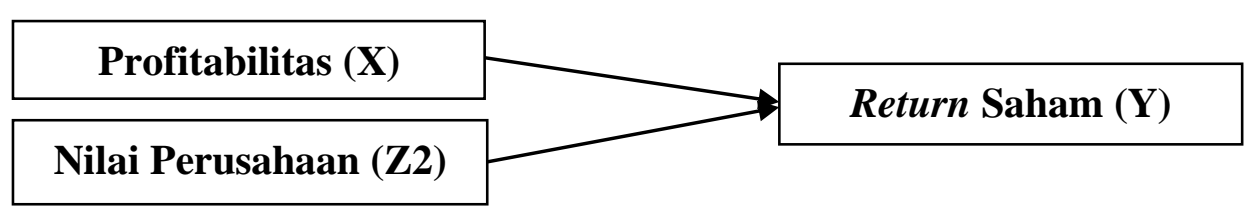
berikut :

Pengujian hipotesis dari persamaan struktural II akan dijelaskan oleh beberapa tabel 
I-FINANCE: a Research Journal on Islamic Finance Vol.06 No. 02 Desember 2020 http://jurnal.radenfatah.ac.id/index.php/I-Finance Destiana Kumala...Pengaruh Profitabilitas Terhadap Return Saham

Tabel 6: Pengaruh Profitabilitas dan Nilai Perusahaan terhadap Return Saham

\begin{tabular}{lrrrr}
\hline Model & \multicolumn{1}{c}{$\begin{array}{c}\text { Standardized } \\
\text { Coefficients } \\
\text { Beta }\end{array}$} & T & Sig. \\
\hline Profitabilitas & & 0,058 & 0,949 & 0,346 \\
\hline Nilai Perusahaan & & 0,900 & 14,752 & 0,000 \\
\hline
\end{tabular}

Sumber : Data diolah, 2019

Jika t-hitung $>$ t-tabel atau $(-)$ t-hitung $<(-)$ t-tabel, maka $\mathrm{H}_{\mathrm{o}}$ ditolak dan $\mathrm{H}_{\mathrm{a}}$ diterima dan sebaliknya jika t-hitung $<$ t-tabel atau $(-)$ t-hitung $>(-)$ t-tabel, maka $\mathrm{H}_{\mathrm{o}}$ diterima dan $\mathrm{H}_{\mathrm{a}}$ ditolak. Besarnya angka t-tabel dengan taraf signifikansi 0,05 dan derajat kebebasan $(\mathrm{dk})=(\mathrm{n}-2)=(65-2)=63$. Dari ketentuan tersebut diperoleh angka t-tabel sebesar 1,66940. Pengaruh profitabilitas (ROE), dan nilai perusahaan (PBV) terhadap return saham adalah sebagai berikut :

1. Berdasarkan hasil perhitungan, diperoleh angka t-hitung sebesar $0,949<\mathrm{t}$-tabel sebesar 1,669, sehingga $\mathrm{H}_{0}$ diterima dan $\mathrm{H}_{2}$ ditolak. Artinya tidak terdapat pengaruh antara profitabilitas terhadap return saham. Besarnya pengaruh profitabilitas terhadap return saham hanya sebesar 0,058 atau sebesar 5,8\% dan tidak signifikan karena nilai signifikansinya sebesar $0,346<0,05$.

2. Berdasarkan hasil perhitungan, diperoleh angka t-hitung sebesar 14,752 > t-tabel sebesar 1,669, sehingga $H_{o}$ ditolak dan $H_{a}$ diterima. Artinya, terdapat pengaruh positif antara nilai perusahaan terhadap return saham. Besarnya pengaruh nilai perusahaan terhadap return saham sebesar 0,900 atau sebesar $90 \%$ dan signifikan, karena nilai signifikansinya sebesar $0,000<0,05$.

Untuk mengetahui kelayakan model regresi digambarkan angka-angka dari tabel ANOVA. Berikut tabel ANOVA :

Tabel 7: ANOVA dengan nilai F dan Sig.

\begin{tabular}{ccc}
\hline Model & F & Sig. \\
\hline Regression Residual Total & 158,015 & 0,000 \\
\hline
\end{tabular}

Sumber : Data diolah, 2019

Apabila F-hitung $>$ F-tabel, maka $\mathrm{H}_{\mathrm{o}}$ ditolak dan $\mathrm{H}_{\mathrm{a}}$ diterima dan juga sebaliknya $\mathrm{F}$ hitung $<\mathrm{F}$-tabel, maka $\mathrm{H}_{\mathrm{o}}$ diterima dan $\mathrm{H}_{\mathrm{a}}$ ditolak. Dari hasil perhitungan diperoleh angka F-hitung sebesar 158,015 > F-tabel sebesar 2,75, sehingga $\mathrm{H}_{\circ}$ ditolak dan $\mathrm{H}_{a}$ diterima. Dengan demikian model regresi tersebut sudah layak dan benar. Artinya, ada pengaruh profitabilitas, dan nilai perusahaan terhadap return saham secara simultan dan signifikan karena tingkat signifikansinya sebesar $0,000<0,05$. Sedangkan untuk melihat seberapa besar pengaruh variabel-variabel yang diteliti terhadap variabel return saham bisa dilihat berdasarkan tabel dibawah ini :

Tabel 8: Model Summary

\begin{tabular}{cc}
\hline Model & R Square \\
\hline $\mathbf{1}$ & 0,886 \\
\hline Sumber : Data diolah, 2019 &
\end{tabular}


Berdasarkan Tabel 8 diperoleh nilai $\mathrm{R}$ Square sebesar 0,886. Angka tersebut mempunyai arti bahwa pengaruh profitabilitas, dan nilai perusahaan adalah 88,6\%. Artinya, sebesar 88,6\% variabel return saham dijelaskan oleh ketiga variabel independen dalam penelitian. Sedangkan sisanya $22,4 \%$ dijelaskan oleh variabel lain yang tidak diteliti dalam penelitian ini.

\section{Pengujian Variabel Mediasi dengan menggunakan Path Analysis}

\section{Stategi Casual Step (Pengaruh profitabilitas terhadap return Saham dengan dimediasi Nilai Perusahaan)}

\section{Gambar 4: Uji Mediasi II}

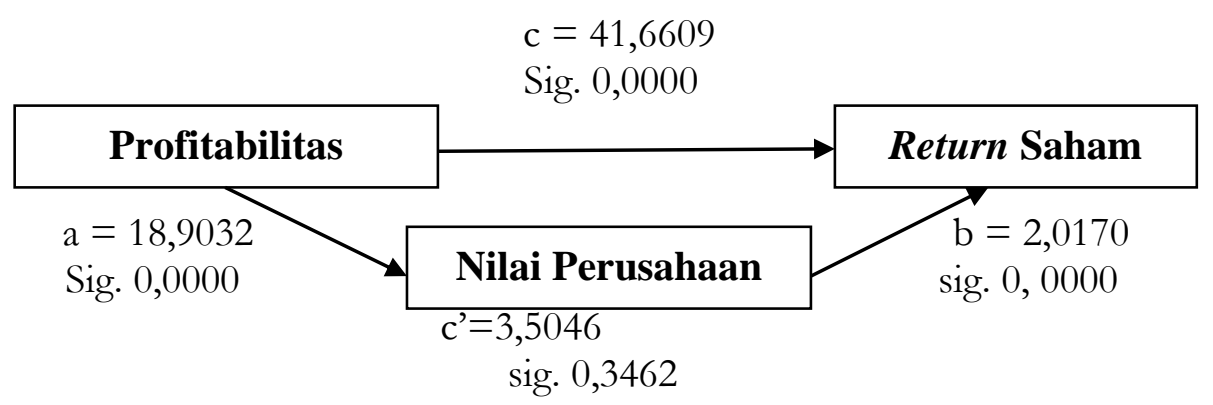

Tiga persamaan regresi yang harus diestimasi dalam strategi causal step adalah sebagai berikut:

1. Persamaan regresi sederhana variabel intervening nilai perusahaan $(Z)$ pada variabel independen profitabilitas $(\mathrm{X})$. Hasil analisis ditemukan bukti bahwa profitabilitas signifikan terhadap nilai perusahaan dengan nilai signifikansi $0,000>\alpha=0,05$ dan koefisien regresi $(\mathrm{a})=18,9032$.

2. Persamaan regresi sederhana variabel terikat return saham (Y) pada variabel bebas profitabilitas (X). Hasil analisis ditemukan bukti bahwa profitabilitas berpengaruh terhadap return saham dengan nilai signifikansi $0,000<\alpha=0,05$ dan koefisien regresi (c) $=41,6609$.

3. Persamaan regresi berganda variabel terikat return saham $(Y)$ pada variabel profitabilitas (X) serta variabel intervening nilai perusahaan (Z). Hasil analisis ditemukan bahwa nilai perusahaan signifikan terhadap return saham setelah mengontrol profitabilitas dengan nilai signifikansi $0,0000>\alpha=0,05$ dan koefisien regresi $(b)=2,0170$. Selanjutnya ditemukan pula direct effect c' sebesar 3,5046 yang tidak lebih besar dari Total Effect c $=$ 41,6609. Pengaruh variabel bebas profitabilitas terhadap variabel terikat return saham dengan signifikan $0,000>\alpha=0,05$ setelah mengontrol variabel intervening nilai perusahaan. Dengan demikian dapat disimpulkan bahwa model ini termasuk dalam kategori full mediation yang artinya variabel independen tidak mampu mempengaruhi variabel dependen secara signifikan tanpa melalui variabel intervening atau mediasi.

\section{PEMBAHASAN}

\section{Pengaruh Profitabilitas terhadap Nilai Perusahaan}

Berdasarkan hasil penelitian statistik dalam menggunakan IBM SPSS Statistic 22 secara Parsial pengaruh Profitabilitas terhadap return saham di peroleh angka t-hitung 
sebesar 7,772 > t-tabel sebesar 1,669, sehingga $\mathrm{H}_{\mathrm{o}}$ ditolak dan $\mathrm{H}_{\mathrm{a}}$ diterima. Artinya ada pengaruh profitabilitas terhadap nilai perusahaan. Besarnya pengaruh positif profitabilitas terhadap nilai perusahaan adalah 0,700 atau sebesar $70 \%$ dan signifikan karena nilai signifikansinya sebesar $0,000<\alpha 0,05$. Sehingga hipotesis pertama $\mathrm{H}_{1}$ diterima. Hal ini menunjukan bahwa besarnya peningkatan profitabilitas akan dipengaruhi oleh Nilai perusahaan.

Hal ini sejalan dengan konsep teory Semakin baik pertumbuhan profitabilitas perusahaan berarti prospek perusahaan di masa depan dinilai semakin baik, artinya nilai perusahaan juga akan dinilai semakin baik di mata investor. Apabila kemampuan perusahaan untuk menghasilkan laba meningkat, maka harga saham juga akan meningkat ${ }^{19}$.

Penelitian ini sejalan dengan penelitian yang dilakukan Loh Wenny Setiawati dan Melliana $\operatorname{Lim}^{20}$ menyatakan profitabilitas berpengaruh positif dan signifikan terhadap nilai perusahaan dengan perolehan nilai signifikannya sebesar $0,000<\operatorname{standar} 0,05$, nilai $\mathrm{T}$ hitung sebesar 13,774 > nilai T tabel 1,96958. Peningkatan margin laba akan meningkatkan kemamapuan perusahaan dalam menghasilkan dana internal. Dengan demikian investor akan tertarik untuk berinvestasi dan harga saham pun meningkat, hal tersebut akan meningkatkan nilai perusahaan pula

\section{Pengaruh Profitabilitas terhadap Return Saham}

Berdasarkan hasil penelitian statistik dalam menggunakan IBM SPSS Statistic 22 secara parsial Pengaruh Profitabilitas (ROE) terhadap Return Saham di peroleh angka angka t-tabel sebesar 1,66940. Sehingga $\mathrm{H}_{\mathrm{o}}$ diterima dan $\mathrm{H}_{\mathrm{a}}$ ditolak. Artinya tidak terdapat pengaruh antara profitabilitas terhadap return saham. Besarnya pengaruh profitabilitas terhadap return saham hanya sebesar 0,058 atau sebesar 5,8\% dan tidak signifikan karena nilai signifikansinya sebesar $0,346<0,05$.

Peningkatan daya tarik perusahaan menjadikan perusahaan tersebut semakin diminati investor, karena tingkat pengembalian akan semakin besar. Hal ini juga berdampak bahwa harga saham dari perusahaan tersebut di pasar modal juga akan semakin meningkat sehingga ROA akan berpengaruh terhadap harga saham perusahaan. return on aset mencerminkan seberapa besar return yang dihasilkan atas setiap rupiah uang yang ditanam dalam bentuk aset ${ }^{21}$

Penelitian ini sejalan dengan penelitian yang dilakukan oleh I Gusti Ayu Ika Yuni Nandani dan Luh Komang Sudjarni ${ }^{22}$ tentang pengaruh profitabilitas terhadap return saham dengan perolehan nilai signifikannya sebesar $0,001<$ standar alpha 0,05 , nilai $\mathrm{T}$ hitung

${ }^{19}$ Husnan, Suad. 2001. Manajemen Keuangan Teori dan Penerapan. Yogyakarta: BPFI

${ }^{20}$ Loh Wenny Setiawati dan Melliana Lim. 2017. "Analisis Pengaruh Profitabilitas, Ukuran Perusahaan, Leverage, Dan Pengungkapan Sosial Terhadap Nilai Perusahaan Pada Perusahaan Manufaktur Yang Terdaftar Di Bursa Efek Indonesia Periode 2011-2015”. Jurnal Akuntansi FE UNIKA Atma Jaya, Vol 12. No.1. hal 29-57.

${ }^{21}$ Wenner R. Murhadi, 2013. Analisis Laporan Kenangan Proyeksi dan Valuasi Saham. Jakarta : Salemba Empat. Hlm 64

${ }^{22}$ I Gusti Ayu Ika Yuni Nandani. Luh Komang Sudjarni. 2017. "Pengaruh Likuiditas, Profitabilitas Dan Nilai Pasar Terhadap Return Saham Perusahaan F \& B Di BEI", E-Journal Manajemen Unud. Vol. 6, No. 8. hal 4481-4509. 
sebesar 3,550 > nilai $\mathrm{T}$ tabel serta hasil uji determinasi sebesar 0, 388 atau sebesar 38,8\% menunjukan bahwa profitabilitas memiliki pengaruh positif terhadap return saham. Nilai ROE yang tinggi dapat diartikan bahwa perusahaan mampu menaikan laba bersih dengan modal sendiri yang dimiliki oleh perusahaan. Hal tersebut akan menarik minat investor untuk menanamkan modalnya, sehingga akan menaikan harga saham begitupun dengan return.

\section{Pengaruh Nilai Perusahaan terhadap Return Saham}

Berdasarkan hasil penelitian statistik dalam menggunakan IBM SPSS Statistic 22 secara parsial Pengaruh Nilai Perusahaan(PBV) terhadap Return Saham diperoleh angka thitung sebesar 14,752 > t-tabel sebesar 1,669, sehingga $\mathrm{H}_{\mathrm{o}}$ ditolak dan $\mathrm{H}_{\mathrm{a}}$ diterima. Artinya, terdapat pengaruh positif antara nilai perusahaan terhadap return saham. Besarnya pengaruh nilai perusahaan terhadap return saham sebesar 0,900 atau sebesar $90 \%$ dan signifikan, karena nilai signifikansinya sebesar $0,000<0,05$.

Nilai perusahaan merupakan persepsi investor terhadap tingkat keberhasilan perusahaan yang terkait erat dengan harga saham ${ }^{23}$. Nilai perusahaan yang dibentuk melalui indikator pasar saham, sangat dipengaruhi oleh peluang-peluang investasi. Pengeluaran investasi memberikan sinyal dari investasi kepada manajer tentang pertumbuhan perusahaan dimasa yang akan datang, sehingga meningkatkan harga saham sebagai indikator nilai perusahaan.

Penelitian ini sejalan dengan penelitian yang dilakukan oleh Septy Kurnia Fidhayatin dan Nurul Hasanah Uswati Dewi ${ }^{24}$ melakukan penelitian hasil nilai perusahaan berpengaruh positif terhadap return saham dengan nilai signifikansinya sebesar $0,000<$ standar alpha 0,05 , serta hasil uji determinasi sebesar 0,166 atau sebesar 16,6\%. Semakin tinggi nilai perusahaan maka akan semakin tinggi tingkat kepercayaan pasar terhadap prospek perusahaan. Hal tersebut akan menjadi daya tarik investor untuk membeli saham sehingga permintaan akan saham naik kemudian mendorong harga saham meningkat.

\section{Pengaruh profitabilitas terhadap return Saham dengan dimediasi Nilai Perusahaan}

Berdasarkan hasil Pengujian Variabel Mediasi dengan menggunakan Path Analysis. Stategi Casual Step (Pengaruh profitabilitas terhadap return Saham dengan dimediasi Nilai Perusahaan) ditemukan tiga persamaan regresi yang harus diestimasi dalam strategi causal step, yaitu Persamaan regresi sederhana variabel intervening nilai perusahaan (Z) pada variabel independen profitabilitas $(\mathrm{X})$. Hasil analisis ditemukan bukti bahwa profitabilitas signifikan terhadap nilai perusahaan dengan nilai signifikansi $0,000>\alpha=0,05$ dan koefisien regresi $(\mathrm{a})=18,9032$.

Sedangkan Persamaan regresi sederhana variabel terikat return saham (Y) pada variabel bebas profitabilitas $(\mathrm{X})$. Hasil analisis ditemukan bukti bahwa profitabilitas berpengaruh terhadap return saham dengan nilai signifikansi $0,000<\alpha=0,05$ dan koefisien regresi $(\mathrm{c})=41,6609$.

${ }^{23}$ Muhammadinah, 2016. Pengaruh Profitabilitas, Resiko Keuangan, Ukuran Perusahaan, Growth, Struktur Kepemilikan Manajerial dan Dividend Payout Ratio terhadap Manajemen Laba pada Perusahaan Sektor Perbankan yang Terdaftar di Bursa Efek Indonesia. Halaman 40

${ }^{24}$ Septy Kurnia Fidhayatin dan Nurul Hasanah Uswati Dewi. 2014. "Analisa Nilai Perusahaan, Kinerja Perusahaan Dan Kesempatan Bertumbuh Perusahaan Terhadap Return Saham Pada Perusahaan Manufaktur Yang Listing Di BEI', The Indonesian Accounting Review. Vol. 2, No. 2. Hal 204-214. 
Persamaan regresi berganda variabel terikat return saham (Y) pada variabel profitabilitas (X) serta variabel intervening nilai perusahaan (Z). Hasil analisis dapat ditemukan bahwa nilai perusahaan signifikan terhadap return saham setelah mengontrol profitabilitas dengan nilai signifikansi $0,0000>\alpha=0,05$ dan koefisien regresi (b) $=2,0170$.

Ditemukan pula direct effect c' sebesar 3,5046 yang tidak lebih besar dari Total Effect c $=41,6609$. Pengaruh variabel bebas profitabilitas terhadap variabel terikat return saham dengan signifikan $0,000>\alpha=0,05$ setelah mengontrol variabel intervening nilai perusahaan.

Dengan demikian dapat disimpulkan bahwa model ini termasuk dalam kategori full mediation yang artinya variabel independen tidak mampu mempengaruhi variabel dependen secara signifikan tanpa melalui variabel intervening atau mediasi.

\section{KESIMPULAN}

Penelitian ini menemukan bahwa profitabilitas berpengaruh terhadap nilai perusahaan, artinya peningkatan peningkatan profitabilitas akan diikuti oleh peningkatan nilai perusahaan dan sebaliknya. Profitabilitas tidak berpengaruh terhadap return saham artinya peningkatan profitabilitas tidak akan diikuti oleh peningkatan return saham. Nilai perusahaan berpengaruh terhadap return saham artinya peningkatan nilai perusahaan akan diikuti oleh peningkatan return saham. Nilai perusahaan memediasi pengaruh profitabilitas terhadap return saham (full mediation).

\section{REFFERENSI}

[1]. Anggraeni, Rr Tini. 2018. Stock Split Dan Pengarubnya Pada Return Saham. AGREGAT: Jurnal Ekonomi dan Bisnis Universitas Hamka Vol. 2 No.2.

[2]. Arifin, Zaenal. 2005. Teori Kenangan dan Pasar Modal. (Yogyakarta:Ekonosia).

[3]. Astiyani , Lany. 2017. Pengarub Profitabilitas Dan Leverage Terhadap Return Sabam (Studi Kasus pada Bursa Efek Indonesia Tahun 2012-2016). Skripsi. Program Studi Akuntansi Fakultas Ekonomi dan Bisnis Universitas Pasundan Bandung.

[4]. Baron, R. M and Kenny, D. A. 1986. The Moderator-Mediator Variable Distinction in Social Psychological Research: Conceptual, Strategic, and Statistical Considerations. (Journal of Personality and Social Psychology. Vol. 51 American Psychological Association. Inc. No. 6.

[5]. Bastian, Herbet, Luh Putu Wiagustini dan Luh Gede Sri Artini. 2018. Pengaruh EVA Dan Kinerja Keuangan Terhadap Return Saham Perusahaan Tambang Batubara Di Indonesia. Jurnal Ekonomi Universitas Udayana Bali Vol.2 No.1.

[6]. Brigham, E. F dan Houston, Joel F, 2006. Dasar-dasar Manajemen Kenangan Edisi 8 Buku 2. Jakarta: Salemba Empat.

[7]. Fadilla. 2018. Buku Statistik SPSS Untuk Penelitian Kenangan, Palembang:NoerFikri Offset.

[8]. Fauzi, Bayu Imam. 2013. Pengaruh Profitabilitas, Tingkat Pertumbuhan, Ukuran Perusahaan Dan Asset Tangibility terhadap Leverage Perusahaan (Studi pada Perusabaan Manufaktur Yang Terdaftar Di BEI periode 2009-2011). Skripsi. Fakultas Ekonomi Universitas Negeri Yogyakarta.

[9]. Ghazali, Imam. 2011. Aplikasi Multivariate Dengan Program SPSS. Yogyakarta:Badan Penerbit Universitas Diponegoro.

[10]. Hartini, Titin. 2017. Pengujian Koalisi Debt To Equity Ratio (DER) dan Earning Per Share (EPS) Terhadap Harga Saham (Studi Kasus Empiris Pada Perusabaan Sektor Makanan Dan 
Minuman Yang Terdaftar Di Indeks Sabam Syariah Indonesia). Jurnal I-Finance Vol.1 No.1. Fakultas Ekonomi dan Bisnis Islam UIN Raden Fatah Palembang.

[11]. Hermuningsih, Sri, Anisya Dewi dan Rahmawati Mujino 2018. Faktor-Faktor Yang Mempengarubi Return Saham, Jurnal EKOBIS Universitas Sultan Agung.

[12]. http://idx.co.id

[13]. Iskandar, Alwi Z. 2003. Pasar Modal Teori dan Aplikasi Edisi Pertama. Jakarta:Penerbit Yayasan Pancur Siwah.

[14]. Kasmir. 2008. Analisis Laporan Kenangan. Jakarta:Rajawali Pers

[15]. Laksono, Cahyo Dwi. 2018. Pengarub Rasio Kenangan Terhadap Return Saham Pada Perusahaan Manufaktur Yang Terdaftar Di Bursa Efek Indonesia. Skripsi (Yogyakarta:Universitas Negeri Yogyakarta).

[16]. Martono, Pemy Aistia. 2018. Analisis Faktor-Faktor Yang Mempengarubi Return Sabam. Media Riset Akuntansi Vol.6 No.1 (Universitas Bakrie).

[17]. Muhammadinah, 2016. Pengaruh Profitabilitas, Resiko Kenangan, Ukuran Perusahaan, Growth, Struktur Kepemilikan Manajerial dan Dividend Payout Ratio terhadap Manajemen Laba pada Perusabaan Sektor Perbankan yang Terdaftar di Bursa Efek Indonesia. I Finance Vol. 2 No. 1

[18]. Nandani, I Gusti Ayu Ika Yuni dan Luh Komang Sudjarni. 2017. Pengaruh Likuiditas, Profitabilitas Dan Nilai Pasar Terbadap Return Sabam Perusahaan F \& B Di BEI, E-Jurnal Manajemen Universitas Udayana. Vol. 6 No. 8

[19]. Husnan, Suad. 2001. Manajemen Keuangan Teori dan Penerapan. Yogyakarta: BPFI

[20]. Noor, Juliansyah. 2011. Metodologi Penelitian: Skripsi, Tesis, Disertasi, dan Karya Ilmiah. (Jakarta:Penerbit Kencana Prenada Media Group).

[21]. Otoritas Jasa Keuangan. 2015. Buku Saku OJK Edisi Ke-2.

[22]. Rembani, Astried Cahya. 2014. Pengaruh Nilai Perusabaan, Kinerja Perusahaan, Dan Kesempatan Bertumbuh Perusahaan Terbadap Return Sabam (Studi Empiris Pada Perusahaan Property dan Real Estate yang Terdaftar di Bursa Efek Indonesia). Skripsi. Program Studi Akuntansi Fakultas Ekonomi Universitas Pasundan Bandung.

[23]. Rucker, K. J. Preacher, D. D, and A. F. Hayes. 2007. Addressing Moderated Mediation Hypotheses: Theory, Methods, and Prescriptions. (Multivariate Behavioral Research, 42(1). Lawrence Erlbaum Associates.

[24]. Saputri, Inayatul Fitria. 2017. Pengaruh Firm Size dan Profitability serta Total assets Turnover terbadap Return Saham Perusahaan Sektor Industri Barang Konsumsi Yang Terdaftar Dalam Indeks Saham Syariah Indonesia (ISSI) Periode 2012-2016. Skripsi (Surabaya:IRPerpustakaan Universitas Airlangga).

[25]. Suganda, T. Renald. 2018. Event Study Teori dan Pembahasan Reaksi Pasar Modal Indonesia. (Malang:CV. Seribu Bintang).

[26]. Sugiyono. 2018. Metode Penelitian Kuantitatif. Bandung:CV ALFABETA.

[27]. Sugiyono. 2008. Metode Penelitian Kuantitatif Kualitatif dan R\&D. (Bandung: Alfabeta).

[28]. Susanti. 2016. Pengarub Current Ratio (CR) Dan Return On Equity (ROE) Terbadap Return Saham Dengan Kebijakan Dividen Sebagai Variabel Intervening (Kasus Pada Perusabaan Manufaktur Yang Terdaftar Di BEI Tahun 2010-2014). Skripsi. Fakultas Ekonomi Universitas Negeri Yogyakarta.

[29]. Van James, Horne C \& Jhon M. Wachowicz JR 2005. Prinsip-Prinsip Manajemen Kenangan, Edisi 12, Buku 1. .Diterjemahkan Oleh: Dewi Fitriasari \& Deny Arnos K. Jakarta: Salemba Empat. 
[30]. Verawati, Rika. 2013. Faktor-Faktor Penentu Yang Mempengarubi Return Sabam Perusabaan Manufaktur Yang Terdaftar Di Bursa Efek Indonesia (BEI) Periode 2008-2013. Skripsi. Fakultas Ekonomi Universitas Negeri Yogyakarta.

[31]. Vidiantoro, Puji Dwi, Nurul Qomari dan Soetopo. 2016. Analisis Pengaruh Likuiditas, Leverage, Aktifitas Dan Profitabilitas Terhadap Kinerja Keuangan Perusabaan Yang Terdaftar Di BEI. Jurnal Ekonomi. Universitas Bhayangkara Surabaya.

[32]. Wardani, Dewi Kusuma dan Sri Hemuningsih. 2016. Pengarub Struktur Kepemilikan Terbadap Nilai Perusabaan Dengan Kinerja Kenangan dan Kebijakan Hutang Sebagai Variabel Intervening. Universitas Sarjanawiyata Tamansiswa:Jurnal Siasat Bisnis Vol. 15 No.1

[33]. Yuliaratih, Kadek Ayu Silvia dan Luh Gede Sri Artini. 2018. Variabel-Variabel Yang Mempengarubi Return Saham Pada Perusahaan Property Dan Real Estate Di BEI. E-Jurnal Ekonomi dan Bisnis Vol.6 No.1 (Bali:Universitas Udayana)

[34]. Zubaidah, Amilia, Bambang Sudiyatno dan Elen Puspitasari. 2016. Pengaruh Kinerja Perusahaan Dan Struktur Modal Terbadap Return Saham (Studi Empirik Pada PerusabaanManufaktur Yang Terdaftar Di Bursa Efek Indonesia Periode Tabun 2013-2016), Jurnal Prosiding SENDI Fakultas Ekonomika dan Bisnis Universitas Stikubank Semarang. 